\title{
Norse Myth and Identity in Swedish Viking Metal: Imagining Heritage and a Leisure Community
}

\author{
Irina-Maria Manea \\ Faculty of History, University of Bucharest, Romania
}

Copyright $(2016$ by authors, all rights reserved. Authors agree that this article remains permanently open access under the terms of the Creative Commons Attribution License 4.0 International License

\begin{abstract}
This paper will be exploring how a specific category of popular music known as Viking Metal thematically reconstructs heritage and what meanings we can decode from images generally dealing with an idealized past more than often symbolically equated with Norse myth and antiquity. On the whole we are investigating how song texts and furthermore visual elements contribute to the formation of a cultural identity and memory which not only expresses attachment for a particular time and space, but also serves as a leisure experience with the cultural proposal of an alternate selfhood residing in the reproduction of a mystical heroic populace. The study case is that of a few contemporary Swedish Viking Metal bands and particularly their appropriations of Norse mythology.
\end{abstract}

Keywords Metal Music, Leisure, Heritage, Norse Myth

\section{Introduction}

First of all, a few considerations about this category are needed. Viking metal, as well as the broader Pagan metal do not entail accurate musical characteristics, they are rather defined thematically and conceptually due to their extensive resort to pre-Christian history. Some bands include older or unusual instruments but the folk element is not a prerequisite for this classification which is actually not unitary and generated externally, for instance in magazines or fanzines. The more general term extreme metal encompasses a wide variety of genres which nevertheless share a few common traits like transgression, a violation of artistic, social, aesthetic boundaries [1]. Heavy metal has already had a long history of transgression, extreme metal stretches it either sonically through a more aggressive and harsh instrumentation, higher level of distortion, guttural vocals, fast tempo or conceptually through stage appearance, occult imagery, comprehensive preoccupation with the dark side of life or, as in Pagan metal, with narratives of ancestry.

It evolved mainly out of Black Metal which upon abandoning Satanic and nihilistic themes and replaced them with sentimentalized visions of the past, although some of the cultural codes were preserved: Black metal artists rejoice in war imagery, fantastic stories and landscapes and above all anti-Christian. The Norwegian scene at the beginning of the '90 (e.g. Mayhem Burzum, Darkthrone) had a major impact on defining the genre and setting its aesthetics, however, Sweden's Bathory played no lesser role, both through the tone and atmosphere sustained musically by lo-fi production and lyrically by flirtating with darkness and evil. More importantly, Bathory marked the shift towards Nordic mythology and heathen legacy in his Asatru trilogy (Blood Fire Death 1988, Hammerheart 1990, Twilight of the Gods 1991).

The attempt at an alternative way to shape an antimodern leisure space turned Bathory and future Viking metal bands away from the ecstatic destruction, misanthropy and elitist individualism in Black metal lyrics and visuals in the direction of ancestral exploitation perceived perhaps as more authentic and appropriate. The Norse element is best noticeable in the album covers that feature Romantic paintings: Nicolai Arbo’s "Åsgårdreien" on "Blood Fire Death" and the graphics depicting warriors in a battle stance on "Hammerheart". Bathory however remained a great deal under Nietzsche's influence with regard to his ideas about spiritual decay and his warnings that this malady is affecting mankind [2]. On the other hand, innovations in the structuring of the songs, clear vocals and chanted choirs added a mark of epicness that will be preserved by future bands that will thematically develop Northern heathenry to greater depth.

\section{Materials and Methods}

Our discussion will center on two theoretical aspects: the building of a cultural identity as a collective self-description [3] and its function as a leisure life-world where one may experience in a liminoid situation the separation from mundanity and integration into a spectacular community [4]. In order to catch a glimpse of the problem, we'll consider materials such as songtexts, iconography and some interviews as well.

Lyrics, artwork and appearance combine and complete 
each other into a view of the past that might be deemed primordialistic on the discursive level. That is, cultural heritage and national/ethnic identity come about in the shape of an unchanging category based on a pre-Christian state of affairs. As every identity, it embodies a historical continuity that forms a common cultural ground while it implies delimitation from some parts of history which are regarded as irrelevant. The cultural representation that these bands offer is that of a given and complete, constituted from within heritage that merely needs to be rediscovered. This idea of a revival of tradition is, however, constructed: the language of music, text and iconography produces meaning and subjectivity by enforcing the impression of unaltered nationhood. In our case that is represented either as Pannordic which is more common or as Swedishness, in which care Norse elements are defined in a more close relationship with the image of an old homeland.

The genre plays with metaphors and symbols and it's not difficult to read in this the basis of a project for community building.

Narratives of history tend to naturalize the social relations of the present showing how they evolved naturally from the past [5] and in order for this to occur one needs to instill cultural meanings regularly embedded in acts like rituals, customs, habits, social codes or collective memories. Shared images and metaphors construct and maintain ideas of solidarity especially where this solidarity is not quite present, as such an imagined community emerges. In this context, heritage provides a vital source of meaning and a sense of belonging. This too can be noticed in Pagan Metal, where on a representational level we're dealing with a discursive construction of subjectivity realized by means of narratives involving a romanticized view of Norse myth, Viking history or Nordic landscape.

It points out to the desire of locality, of rootedness in the quest for a positive identity in a post-modern world [5]. In this sense resorting to the ancient past might be considered an act of imaginative rediscovery which this conception of a recovered, essential identity entails [3]. What's interesting in these stories which among others Pagan Metal serves us is that they are by far discourses of some marginalized or deprived categories. Some other interest is rather at stake: a celebration of difference that brings subjects into being in that they assume a part of history as their main identity building block. Furthermore, this identity can better be understood not as an entity but as an emotionally charged description [3]. As we shall further discuss, community is at the same time expressed through the construction of a tribe-like collectivity of imagined warriors.

Popular culture attempts to utilize history, landscape or gender within representations which interpellate $[5,3]$ in other words hail us to produce and affirm a certain type of subjectivity. Pagan Metal might imaginarily evoke a historical and geographical locality turning it into a collective memory. That is not to say that the artists are unaware of this, but that they somehow seek both to reenchant the modern world with mythical images and to imprint a sense of revitalized memory.

Scholarly work on metal music does not have a long history, contributions were published in the 90s and 2000s. Deena Weinstein's "Heavy Metal: The Music and its Culture" (1991) is a sociological study dealing with the music, its makers, fans, dress codes, the rebellious aspects and myths surrounding the culture. In "Running with the Devil. Power, Gender and Madness in Heavy Metal Music" (1993), Robert Walser explored how metal functions musically and socially, investigating the formation of identity, community, power and gender. Sociological, musicological, psychological or gender and identity studies approaches have become common (see G. Sharpe-Young, "Metal: The Definitive Guide", G.T. Pillsbury, "Damage Incorporated: Metallica and the Production of Musical Identity", J. Wiederhorn: "Louder than Hell. The Definitive Oral History of Metal", D. Weindl: "Musik \& Aggression: Untersucht anhand des Musikgenres Heavy Metal", A. Mombelet \& S. Walzer: "La Religion Metal: Sociologie de la Musique Metal" and so on. The extreme scene on the other hand has not been so well tackled and caught academic attention in the past 10 years. K. Kahn-Harris in "Extreme Metal: Music and Culture on the Edge" explores the scene as a space where members toy with destructive themes and simultaneously create a community delimitated through transgression.

Whereas subgenres like Black and Death Metal imagologies and rhetoric have been discussed especially in terms of subcultural capital in several contributions e.g. N. Pucell, "Death Metal Music. The Passion and Politics of a Subculture", K. Jones: "A Blaze in the Northern Sky: Black Metal Music and Subculture. An interactionist Account", C. Dornbusch \& H.P. Killguss: Unheilige Allianzen - Black Metal zwischen Satanismus, Heidentum und Neonazismus" or J. Foster" Commodified Evil's Wayward Children: Black Metal and Death Metal as Purveyors of an Alternative Form of Modern Escapism, the Pagan/Viking fringe has received little attention. The above mentioned works are however relevant because they include the idea of a romanticized past and nature. Viking Metal is tackled in materials written by F. Heesch: Metal for Nordic Men. Amon Amarth's Representations of the Vikings", I. von Helden: "Scandinavian Metal Attack! The Power of Northern Europe in Extreme Metal", "Antichrist Superstars: The Vikings in Hard Rock and Heavy Metal" or A. Washley: "A Great Heathen Fist from the North". This article comes as a completion in this burgeoning area, by inserting representations of a mythologized heritage in popular music into a leisure studies framework and commenting on the invention of the "North" in a particular scene.

\section{The Pagan Revival in Swedish Metal. Månegarm and Thyrfing}

The idea of mythologizing origins and narratively shaping 
heritage reminds of the notion of invented tradition. From this point of view, ancient materials are constantly being recycled to serve novel purposes. A great deal of such materials is accumulated in the past of every nation, society or group and elaborate language of symbolic practice is always available [6]. Invention here does not necessarily refer to fiction, but rather to imagining all sorts of connections and continuities between historical phenomena. Whereas popular music does not necessarily entail a regulation of a status or relations of authority, it does contribute to the establishment or symbolic codification of membership.

In the case of Swedish Viking Metal, there occurs a development, or staging, of multiple identities: musical, Scandinavian, Swedish. Musical since Viking is part of the larger conglomerate known as extreme metal, Scandinavian due to the shared themes and desire for a trans-national belonging and Swedish because now and then the artists attempt to use more direct references to the local backdrop reinforcing the connection to Nordic antiquity. To all these however we can add a so-to-speak recreational identity, an invented collectivity that corresponds to the postmodern struggle for the reconstruction of communities in an era of fragmentation, anxiety, contingency and ambivalence [4]. The need for belonging to some kind of home translates into shaping forms of togetherness which are varied and deviate from those normally considered by sociology. Community nowadays is more like an assemblage of self-assembly kits as a means to escape an everyday life perceived as depthless and impermanent [7]. In other words, there is a need for an "us", a togetherness which Pagan Metal envisages by framing-up groups of ancient warmongers with an air of mysticism and wonder.

To begin with, a search on the Encyclopaedia Metallum which serves as a primary source for discographies (metal-archives.com) with keywords Viking Metal will reveal a number of 36 bands, about half of them active or with albums released. The Norse element is present from the very beginning in some of the bands' names: Odenwrath, Fimbultyr, Thyrfing, King of Asgard, Odhinn. Then, while taking a glimpse at the lyrical universe, Norse mythology obviously tops the mentions, but is sometimes accompanied by tangent theme Vikings (Mythotyn, Odenwrath, Thyrfing, King of Asgard, Prophanity) nature (Odenwrath, Irminsul, Vintersorg, Stellar Winter), anti-modernity (Son of the Northstar), folklore (Irminsul, Nattsmyg), heritage (Asynja, Månegarm) or patriotism (Allegiance). One band, Asynja, draws attention with the label Aryanism and another one, Fyrdung with the label NS, but generally speaking such terms are not common. Album titles may allude to warfare ("Raise Your Swords" - Feskarn, "Blodshymner" - Feskarn, "Vredes tid" - Månegarm, "Stronger than Steel" Prophanity), Nordicness ("The North Brigade" - Odhinn, “...to North" - King of Asgard, Nordstjärnas tidsålder, Legions of the North - Månegarm) or/and mythical facets ("The Ravencult" - Odenwrath, "Thyrfing" - Thyrfing, "Irminsul" - Irminsul, "Fi'mbulvintr" - King of Asgard,
"Fylgja" - Nattsmyg, "Ragnarök" - Fyrdung, "Hymn till hangagud" - Allegiance). Norse mythology, as expected, appears in the titles of many songs: "Speech of Odin", "Mot Jotunheim", "Ulfhednar", "Einhärjar", "Nifelheim", "Allfader" and many more.

The lyrics are filled with mythological content, ranging from the gods who populate the stories to retold mythological tales. In all these stories we can notice stock images, so to speak, for instance the imagery of the battle and hypermasculine warrior, the specific depictions of landscapes or the praise for an unaltered past as opposed to the modern Christian world. In an attempt to detail such aspects we will have a look at several bands and their lyrical content, with the mention that a lot of the themes are recurrent in the genre and the diversity of borrowed material from the Eddic sources is rather limited. More importantly, Norse myth functions as a signifier for the construction of an imagined locality dwelling on anti-Christianity, anti-modernity and a praise for an idealized version of a glorious antiquity. All these elements combined create empowerment and may be linked to the general transgressive practices of extreme metal music which promotes an iconoclastic dialogue with other genres, testing and breaking boundaries, invoking the joys and terrors of formless oblivion within the collective while bolstering feelings of individual control and potency: sonic, discursive, bodily transgression [1]. Empowerment occurs through the instilment of a feeling of pride and epicness everyone can take part in, because as mentioned before, although we are dealing with certain cultural markers, Viking metal is an open cross-culture in that anyone can assume and affirm this theatrical Nordic identity.

Månegarm, founded in 1995 in Norrtälje, has been quite prolific releasing eight full-length albums from 1998 to 2015. Their Pagan self-image of "Swedish Vikings" is underlined in the name itself, taken from the prose Edda: Mánagarmr, a giant wolf who will devour the moon during Ragnarök. The wolf, present on the band's logo as well, has a tremendous significance for the band, signifying freedom and wildness, beauty and fear, something that lives inside every man [8]. Northern wolves as powerful metaphors of the self can be found repeatedly throughout the discography, in songs like "Havets vargar", "Vargbrodern talar" or "Vargstenen". It alludes to Ulfhéðinn, the saga-warriors capable of performing great deeds due to the possession by the animal spirit. The texts explore a variety of Norse themes, striving to design an atmosphere of magic and heroism meant to function as what we might deem as an escapism into the archaic.

"Ymer" relates about the cosmogonical myth. Odin with his proverbial wrath makes an appearance in "Vanvett" where he joins Freyr and giants like Suttung in a display of frenzy, in "Dödsfärd" or "Daudr" where he is associated with his great hall of fallen warriors or in "Vargstenen" where he symbolizes ancient wisdom through his one eye. Sometimes Odin can appear under another name like Grimnir, used in Grimnismál, and in lines resembling a hymn: in 
"Vedergällningens tid", "the sons and daughters of the North", of Midgård, seek the help of the almighty father in order to resist in the battle mania for retribution and the recovery of tradition. Thor is also greeted as a helper for sustaining the "Nordic battle rage" with his hammer in "Tor hjälpe". Åsgard makes the scene alongside Midgård and in "Mina fäders hall" or "Legions of the North" it suggests a place of ancestry from where the army of Vikings draws its force. Other mythical cast includes ravens, Odin's companions, Aegir the sea god, bridge Bifröst that stands between the human and divine realms, worlds of ice and fire Nifel and Muspel, the prophetesses named Norns especially Urd, patron of the past, mighty oak Yggdrassil, goddess Hel and the realm of death, spring Hvergelmir, Valkyries who take the souls of brave warriors, Hrimfaxi the night horse, giants or fylgja, a kind of spirit in connection to fate. Interestingly one may notice two further characters which do not stem from the Eddas: Nerthus in "Nattväsen", a fertility goddess mentioned by Tacitus for the Suebi tribes, and Sunna, a personification of the sun hinted at in the Merseburger incantation and found under another name in the Edda.

Furthermore, we can follow the construction of the "North" category not only by resorting to mythical material, but also to lexical items pointing in the same direction of a mythologized heritage and community. So we may encounter formulae such as "nordanblod", "nordens land", "nordstjärna", "nordens vargar", "nordbaner", "nordens mark", "Nordic battle rage", "Northern ground". Associations like "legions of the North" increase the overall antiquing sensitivity. Swedishness as an even more specific marker expresses itself first and foremost by means of the language, utilized extensively, but otherwise not much. We do have a reference in "Gryningstimma", namely the halls of Svithjod, a gathering held at Gamla Uppsala and mentioned in Heimskringla. The salvation of the land is a rather overused theme, but it can refer to the larger Scandinavian landscape.

A revitalization of ancestry is generally expressed through violent imagery, which in fact represents one of the genre conventions of heavy metal, yet in the case of Pagan metal it is adapted to more specific messages. The lyrical archaic self-representation revolves around the warrior type who assembles highly masculine traits around conservative notions of heroism that point out a gendered pattern also found in the musicians' combative stances and gestures in shows or magazines. Beards, long hair and tattoos are also signifiers of this alternative ideal to the neat contemporary posture. The martial approach characteristic of the whole genre and in the case of Viking metal expressed in a cult for the barbarian could be interpreted as a form of escapism and empowerment. Moreover, the myth of the warrior is integrated into the larger identity-shaping myth of rootedness whose affirmation occurs within the opposition between a romanticized virtuous past and Christianity standing for a disenchanted and oppressive modernity.
"Our pagan souls have awakened

feel the hate... pagan war

Feel the pagan in your heart, Now feel the pride flow".

("Pagan War")

The rather essentialist view celebrates heritage and ancestry not only as themes, but are somehow perceived as real, true ancient stories as well as fantasy stories [8]. This perception manifests a stylized Nordicness full of enchantment and catchiness drawing loosely on a past that becomes a source for an imaginary place, [9] a local or national scene that plays with connections to the heathen past. Markers for this imaginary place are heavily utilized in iconography. The CD artwork focuses on primary archaic symbols reiterated in the song texts, the wolf, Viking warriors, Viking ships, a runestone and perhaps the most suggestive, trolls bringing down a church on "Vredens tid". Backdrop images focus on seas, mountains, storm, mystifying nature into an aggressive companion and Nordic element. Whether a greenish scene evoking ancient soil on "Vargstenen", bloody strong nuances on "Vredens tid" or "Havets vargar or greyish dark on "Legions of the North", the pictures and their characters offer recognizable codes from heavy metal and popular culture in general, and on the other hand artistically underline a Northern identity. It is, so to speak, a self-created authenticity.

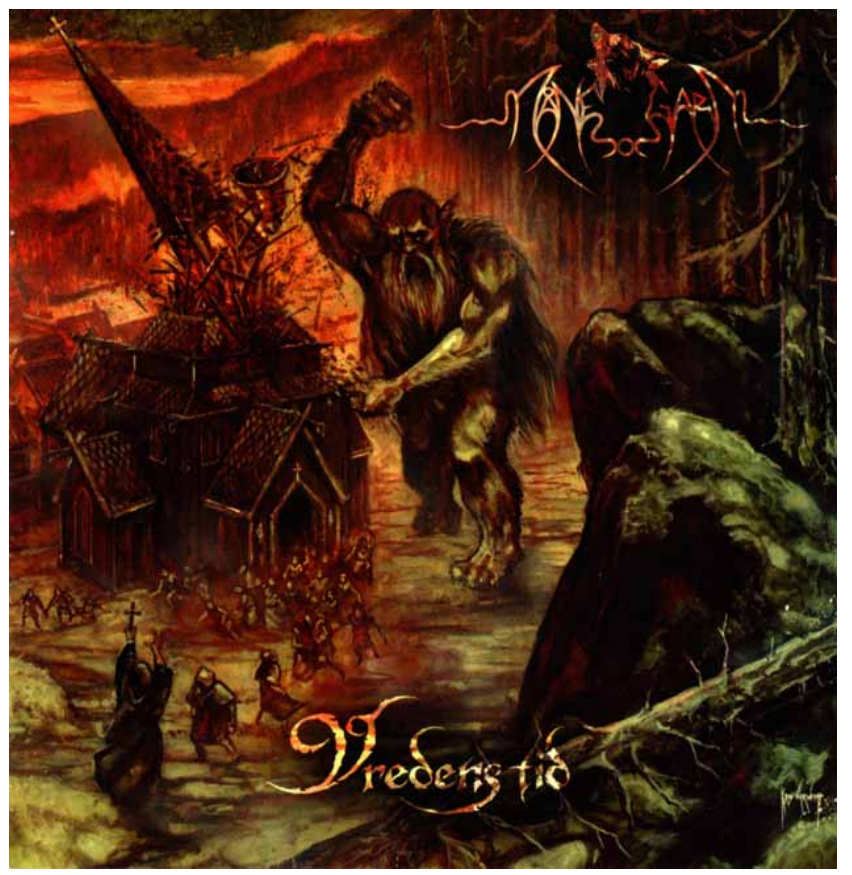

Figure 1. Cover "Vredens tid"

Another example to be tackled is that of band Thryfing, which uses the same patterns of instrumenting myths in order to create an escapist atmosphere. The Norse signifier can be noticed in the band's name itself, a magic sword found in the poetic Edda and in Hervarar saga. Interestingly, the name is also used to designate the Goths, which formed the base of a cultural movement in Sweden that focused on the myth of the 
ancestors identified precisely with the Goths. In the 19th century there was even founded an association, Götiska förbundet, with the purpose of researching Norse mythology in order to revive the honor and glory of the old Goths [10] therefore in an idealistic attempt to sustain national identity. A similar preoccupation with ancient themes framed in a significant landscape that imagines a spectacular North and builds up a togetherness. All these reiterated gods, heroes and their deeds create some sort of historical continuity rooted in a need for power, a will to live that shapes the communal spirit of the lads, giving their leisure life-world vitality and group identity [4].

The band founded in Stockholm in 1995 released seven full-length albums between 1998 and 2013 and makes extensive use of Norse material. In "Vargavinter" the wrath of the Aesir is directed towards Midgård's new god whose light is bound to fade. Tyr, Odin and Thor are offered hymns by the fierce Viking fighters in "Set Sail to Plunder". Odin preserves his roles as warmonger, leader to victory in the battle for the recovery and revival of the Pagan land and almighty father of the Vikings in "Ur askan ett rike", "Askans rike" or "Hednaland. Odin is further explored under other names: Wotan, as recorded in Old High German ("Wotan's Fire") or Valdr Galga (ruler of gallows, another name for Odin) in the homonymous song which relates the story of his hanging in Yggdrassil. The mention of Bolthorn, the frost giant who was also Odin's maternal grandfather, Niddhogg the dragon gnawing the roots of the world tree or of Othaerir, the vessel keeping the mead of poetry asserts a preoccupation with Norse elements which goes beyond buying Mjölner pendants and claiming to be a Viking [11]. Rather than religiosity it is more likely an attempt at authenticity gained by a more complex approach of the old sources.

One can notice in these songs the dichotomy between Christianity and Paganism on the one hand and the warrior self-image linked to the community image through the oscillation between first person singular and plural. Warriors and gods form an invincible Nordic army. War as an ecstatic experience is thematically expressed through the ideal of the berserker embodying hypermasculinity, perhaps the strongest motif suggesting empowerment ("Going berserk", "Firever"). Valhalla's fighters accompanied by Valkyries, with the distinct focus on their Heathenism, are glorified in "A Moment in Valhalla" or the individual warrior seeks to be joined with the Valfader as Einherjar ("Till valfader urgammal") . Cosmogonical references involving Ymer the primordial giant and the sons of Bor, Odin and his brothers, in "Mimer's Well" come together with a lament over the old times and an apocalyptic titillation articulated by the first person narrator identifying as Odin as speaking from his throne Hlidskjalf. This primordialist approach to a past in need of celebration entails however a certain millenarianism brought in which Odin's warlords will prevail ("A Great Man's Return"). Minor mythology is also present, like draugr, an undead creature ("Draugs harg"), which comes to symbolize the lack of meaning in the modern man's life [11].
Beginning with "Vansinnesvisor" the band marks a shift in the lyrical concept by rather exploring more personal feelings. Until then nevertheless they manage to shape a very powerful image of a collective identity of the Nordic barbarians.

"A Viking and his warriors built a dragonship They're going out to conquer a feeble land Heavily armed with swords, axes and shields The swedes set sail for weaker ground Chanting hymns of Tyr, of Odin and of Thor A Viking shall but win, berserker deep inside" ("Set Sail to Plunder")

As in the case of Månegarm, Nordicness is constructed lexically by phrases like "northern soil" ("Storms of Asgard"), "northern land" ("Arising"), "northern king" ("A Great Man's Return"), "nordens styrka" ("Mjölner"), "nordstjärna", "nordens själ" ("Urkraft") and so on. This last song might be considered particularly relevant since it addresses the concept of an ancient energy which feeds this community of Pagan warriors, leading them to victory on the Vigrid plains. Furthermore other markers point out the construction of this mystical and spectacular world: ravens, wolves, seas, mountains, rivers. Nordicness specializes in Swedishness perhaps a little more than in the case of Månegarm, not only through the extensive use of the language, but specific formulae narrowing down the constructed heritage site: home is synonymous with Sweden - "Vikings got their goods [...] found their way to Sweden. Thor's hammer is interpreted as a symbol for the greatness of the kingdom Svea, alluding to the patriotic emblem and female personification of Sweden in song "Mjölner". Mother Svea reveals itself as a romanticized landscape that left a mark in the warriors' hearts ("Home Again") and cradle for "a Pagan race" meant to wreak havoc and brought into being by the gods themselves ("Sweoland Conqueror"). We can notice therefore a tendency to mythologize the nation in such narratives through retelling myths of origins.

Mobilizing myths constructs rootedness and points out a commitment to locality reminiscent of the blood and soil notion. The effects might be two-fold: on the one hand an invigorated pride associated with the celebration of regional heritage and on the other hand a reenchantment of the world because of the resort to images of a distant past serving as a base for root revivalism but in the same time for an imagined group bonding focusing on an imagery of masculinity, heroism and power that comes as an offer to the possible feelings of alienation in the globalized modern world. After all, we should not neglect the recreational value of narrating such epic stories and the fact that they belong to the larger category of metal music whose conventions include aggressive displays of masculinity and the more specific category of Pagan metal which focuses on archaic symbols to induce escapism. And speaking of conventions, stylistic codes run throughout the artwork of Thyrfing as well. We have brave Vikings and their ships, nature and its gloomy side ("Thyrfing"), mythical characters ("Valdr Galga"), 
intricate patterns reminiscent of Viking art ("Urkraft") and also visual suggestions of the warrior type in the musicians' appearance.

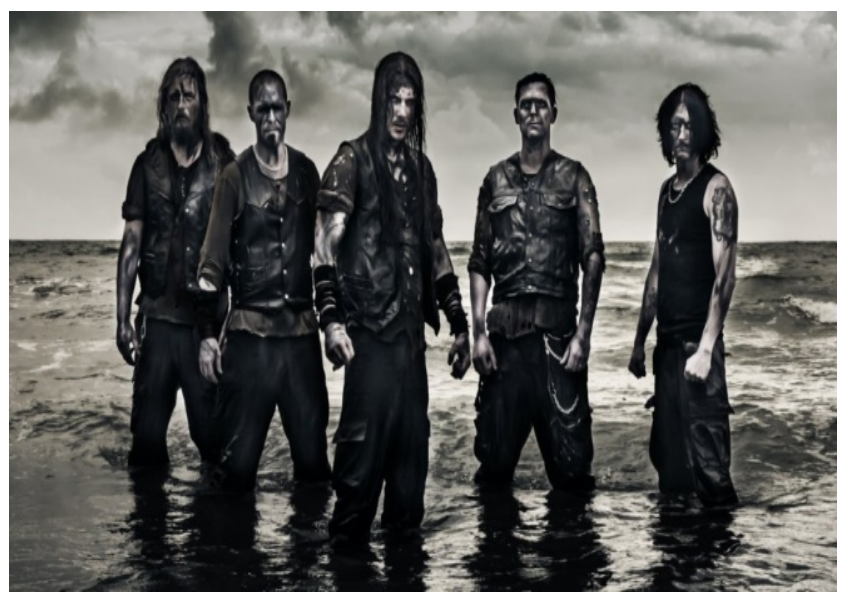

Figure 2. Band photo

Other bands follow the same convention: an artistic approach dwelling on Northern antiquity with a touch of Swedish locality. Feskarn utilizes the themes of Odin and Valhalla, the myth of the homeland and its defenders, the Birka warriors. Battle roars also abound in the lyrics of band Prophanity. Apocalyptic and post-apocalyptic images enclosing characters like the surviving gods Vidar and Vale are preferred by Fimbultyr. Ereb Altor does not refrain from prophesizing of the ressurection of the old order either, or about sacrifice or the special destiny of the Norse community, "The Chosen Ones" descending from Ask and Embla as one song puts it. The same band enforces the idea of the sacred legacy identified with the land from the North. Grimner narrates about the rage of the berserker, adventurous journeys under the sign of the gods or fantasizes in a nostalgic note about the loss of heritage and values. The theme of the ancestors calling for a rediscovery of some ancient wisdom is among the most common in this genre, as shown in Irminsul's "Letters from the Past". This band is remarkable for its resort not only to the usual gods and heroes, but also to folklore or sagas, as in the example of "Hagridden", a song that retells the story of the mythical Swedish king Vanlandi from Ynglinga Saga.

As expected, artwork sticks to the codes as well, including representations of nature ("Megin" cover, Son of the Northstar), musicians as warriors ("Ravencult", Odenwrath), runestones ("Östra Aros", Feskarn), wolves and night ("Fi'mbulvintr", King of Asgard), mythical scenes ("Hymn till hangagud", Allegiance) and so on. Such samples are indicative of the way representatives of Pagan metal shape their aesthetics and identity by inventing a tradition that presupposes continuity between the past and the present. Here myths play a fundamental part, because they recast and spiritualize self-images of communities and present them as timeless and interchangeable with history. In a few cases however this quest for identity structuring can suffer a radicalization. Group Asynja linked to the now closed label
Nordvind which specialized in Rock Against Communism, instruments mythical items to give an expression to a political agenda which is overtly stated in lyrics such as "let the valkyrie ride by the white man's side and sing the racial song!" or the apology of a Germanic nation ("Fadernass kall"). These radicalizations of contemporary identity building are nonetheless a marginal phenomenon.

\section{Discussion}

\subsection{A socio-cultural context for Viking Metal}

As suggested before, Viking/Pagan Metal has its origins in the breaches of the metal scene which in their turn formed other scenes since the early and mid-1980s. We may think of scene as a kind of context for musical practice, a flexible loose space of its production [1] and a set of connections within a locality or style form. This is the narrow meaning. The broader meaning adds a note of displacement, comprising a fluid, flexible, globalized network of artists and fans.

Any cultural product can be understood in terms of both reproduction and resistance [12] and these two usually come in a circle.

Heavy metal, by flirting not only with a more aggressive sound but also with controversial themes ranging from hedonism to the occult, gained a transgressive state, but one which was called into question given its subsequent mainstreamization. In other words, a new resistance came about, one as a reply to metal's flirtations with pop sounds and styles [13]. Getting more extreme in musical or thematic content was an attempt to avoid imitation. Subgenres like thrash, speed, death, black or doom expressed dissatisfaction with the hedonistic glamorous touch and were in the process of their own individualization. Nordic bands have utilized landscape and history so as to aesthetically shape an idea of North reflected both in raw atmospheric sounds and imagery abounding in representations of wild nature, adventurous journeys, epic battles or mythical stories that were culturally set in Scandinavia and played with a romanticized and masculinized version of the "North". Nonetheless, this type of semiotics was more noticeable in the case of $90 \mathrm{~s}$ Norwegian Black Metal which actually became a label itself. More elements such as instrumental and choral passages, an iconography that mimicked the cold bleak environs of the north [13] underlined this distinctiveness. Sweden rather made a name for itself through Death, not Black Metal at first, with the so-called Gothenburg scene as the center of a specific, more melodic form of the genre. Death metal, whose traits include heavily distorted low-tuned guitars and deep growling vocals, does not utilize local symbolism to the same extent, rather focusing on social, philosophical or political themes that are of international significance and resorting to heavily stylized violence as textual and visual marker.

On the other hand, one should not essentialize the relationship between music and its external conditions, in the 
sense that more than often the evolution and characteristics of the sound or lyrical content determines certain labels. Viking metal itself with all its passions for Nordicness has been globalized because as a leisure product its appeal through the romance of ancestry (that in other parts of the world might be understood as a romance of otherness, of the exotic) and the empowerment quality discussed above. The lyrical focus on Norse heathenry exceeds genres which all the same overlap enhancing innovative approaches. Besides the already mentioned contribution of Bathory to the development of this Norse recreational ground, Swedish death metal bands Amon Amarth and Unleashed played a considerable part in broadening the Pagan scene by incorporating Viking themes and thus replacing the traditional gory imagery in the same manner Black metal bands like Enslaved replaced the satanic one.

If we ponder about the Scandinavian roots of this cultural product we might trace it to a few contextual traits that could have enabled its emergence: the cultural legacy of myth and folklore that prevailed long after the introduction of Christianity. In relation to this we could also mull over anti-Christianity as both a reaction to a protestant/evangelical tradition quite strongly supported institutionally and less of a personal asset, therefore perceived as foreign or unnatural and a more general reaction to normativity, anti-hedonistic attitudes, a uniformity of civilization or an internationalization of values to which this leisure community opposes a vision of heathen freedom. A history of censorship of violence and the macabre and relative cultural distance from Europe could also have been favorable [2]. The high living standards as well as the recurrence of topics related to equality and multiculturalism could as well share a part in triggering an identity quest closer to locality and heritage. Still, as indicated before, we should not overemphasize this aspect but also take into account the leisure value of this popular discourse about Norse folkways and the establishment of gods and barbarians and their storylines as stock package for the heavy metal world.

In the same time we should take into account the larger picture of the extreme metal scene and, as mentioned earlier, the very important idea of trangression which implies controversies as a tool for both identity and marketing. The deliberately offensive sonic landscapes, lyrical content and physical imagery of some genres are generated from within [14], so they're not only the product of some media or outsiders' discourse, but also intentionally as a way to create boundaries. 90s Black Metal including Mayhem, Burzum or Darkthrone resorted to an aesthetics of evil so as to define itself, creating its countercultural image by resorting to a mythical storyline which opposes highly romantic versions of Satanism and Paganism and the tyrannical and imperialistic picture of Christianity. They developed a dark leisure where they stage themselves as pseudo-Vikings and toy with taboo areas by means of power images. By and large, Black Metallers recycle a cultural image of Satan that brings forth his revolutionary symbolism, the rebellion against authoritarianism in favour of individualism. The Viking fringe also feeds on inherited cultural images. Norse mythology has experienced throughout history a series of revivalisms and is still one of the most appreciated sources of inspiration in modern popular culture, which brings us to the next point.

\subsection{Heritage, Communion and Leisure}

Generally speaking Viking Metal does employ a primordialist view of heritage and on a discursive level this mythologized Nordic ancestry constructs an identity in a rather high-end elitist fashion, either a broader Northern one or a more local Swedish one. If we were to apply semiotics here, we would say that there are certain markers (in this case we discussed narratives and artistry populated by gods and heroes) that pinpoint certain sights (in this case the Scandinavian landscape with its heritage). Both sights and markers are culturally constructed within a mixture of symbols that unfold a story that offers meanings in a condensed form [15]. That means that representations in popular culture suffer from an overlapping of symbolic layers which all in all organize a leisure space. One structures images of heritage in such a way that the audience might be able to relate to them. How Norse mythology is incorporated into narratives of Viking Metal depends on the many receptions and usages it had in the course of time, in romantic, nationalist or Neopagan movements, as well as on other representations in the media, that is, how the Viking age is depicted in movies, comic books, novels etc., all of which flowed into myths and stereotypes for mythology itself, now a building-block for recreational space where both musicians and audience can rejoice in the possibility to identify with the imagined community of archaic warriors and their heroic quest for primal roots.

This image is part of a broader cultural inheritance. Nineteenth century Romantics were fascinated with mythology in general and Edda material inspired poetry but national projects as well as in the case of Jacob Grimm or Richard Wagner who despite a Germanization of places or characters remains attached to the Icelandic sources. The blend of myth, history and nationalism led to a perversion of these stories in right-wing symbolism that nowadays is still used in propaganda thus sometimes raising the issue of political values in popular culture as well. Explicit racial ideologies are however very rare in the scene and when they do occur, right-wing discourses have an ambiguous status, in the sense that political purposes might not be the main preoccupation here. The appropriation of National-Socialism can as well be thought of as another way to break taboo zones and maintain the controversial nature of extreme metal in general, something designated as reflexive anti-reflexivity [1]. In other words, the escapist offer can embrace various offers of commodified evil, testing the boundaries of acceptable norms and practices. So extreme nationalist concerns can also be read in this manner and political, militant connotations remain marginal in the scene. 
Recovered in popular culture ranging from J.R.R. Tolkien and J. L. Borges to comic strips and Marvel movies, stories about Norse gods and heroes are recast in different forms that are embellished and mainly preserved only core elements from old sources, but regardless of their form, what we can remark is their dramatic and emotional appeal: exciting adventure tales form the basis of an escapist space where one can enact exuberant fantasies. In the same time, when resorting to such emotional histories as alternative (dark) leisure some sort of spirituality comes as a form of cultural criticism which is to be found in heathen revival movements as well. In a fragmented postmodernity new identities are sought in the guise of a multitude of cultural niches that play with norms and codes. Pagan Metal enacts ethnomythical martial selfhoods and imagines an archaic collective feeling that involves categories of masculinity and whiteness. Given the instrumentalization of such categories in politically laden contexts and völkisch worldviews which share the common ground of Norse myth reception, confusion over their overlappings might occur. That's why it is important to regard Pagan Metal in the broader context of cultural fragmentation, scene coding and leisure.

Furthermore, musical features, song lyrics, graphics, visuals at performances and musicians' own interpretative narratives about their work generate a sense of cultural otherness, mystery, ancient wisdom.

Music plays an important part as a cultural instrument through which people manage and explore identities and emotions and at the same time acts as a site for transmitting alternative spiritualties [16] as we can deduct here, Viking Metal perpetuates a cultic admiration for ancestry, collectivity and masculinity and Swedish VM in particular keeps up and reinforces these conventions while it alternates between grasping a local, "Svea" or Northern identity which to a great extent overlap.

Either way, we can say the past is antiqued and gentrified, becoming a static image of how things used to be. The gods and their stories are also presented as being part of Norse history and in a claim for sentimentalized authenticity contemporary Vikings (there is a recurrent use of the $1^{\text {st }}$ person plural) set the task of restoration. Therefore, Norse myth and history are united in a collage of fictions reinventing national and trans-national heritage as a response to what is perceived as an alienating and meaningless modernity for which Christianity stands as a symbol. This reminds of an overall characteristic of heritage industry, namely that it is mainly about nostalgia [17]. But, as popular culture itself, it is also about consumerism. The discourse of the past in Pagan Metal is produced and consumed as well, if we think about festivals like Ragnarök held in Germany since 2004 (and participation extends beyond these specialized events) or about the piles of merchandise present at every concert. Clothes and accessories are important in this scene since they insure the preservation of its cultural conventions, not to mention all the sites or Facebook pages that gather both musicians and fans.

If we were to borrow a term from culture industry, we might say that the stylistic codes of the genre contribute to a gentrification project, merging culture and commerce [1]. In popular culture one can break down and rearrange familiar and unfamiliar elements, reconstructing history in an idealized manner which brings in into the playground of fantasy and magic.

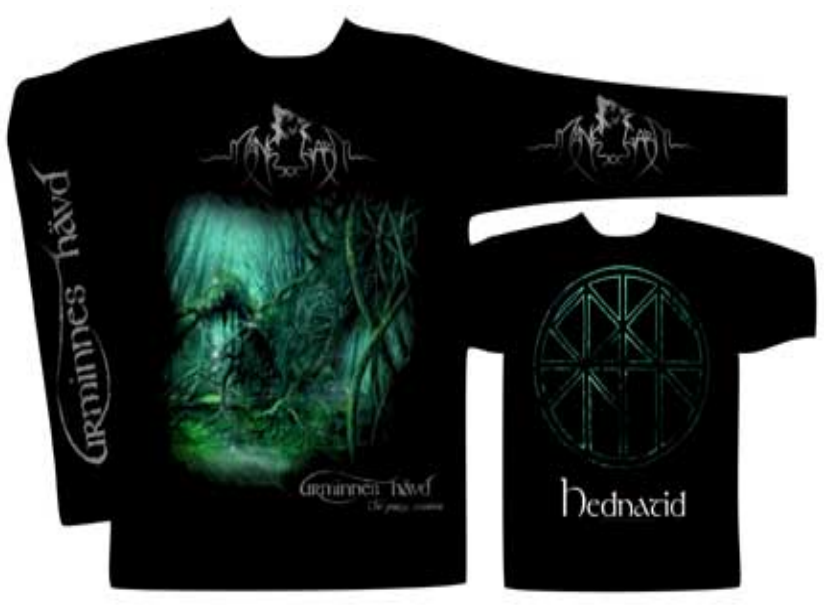

Figure 3. Månegarm clothing

Apart from the focus on notions of origin, the appeal of Pagan Metal is also accomplished by means of the somehow tribal collective identity it shapes in the form of a tribal, lads' community, the image of the archaic barbarians plundering and pillaging and praying to the Norse gods. Leisure life-world can provide with intimations of authentic selfhood [4]. This authenticity is however staged, as part of the escapist nature of metal music entailing empowerment through a stylized hypermasculinity, a discourse which doesn't seduce only males since, as stated before, it is a playground of identities involving a decentering of the self and an active identification with mythical characters be it only by listening to the respective music.

Coming back to the sense of community achieved through this link between a romanticized heritage and an escapist warrior myth we might invoke the notion of mythogenesis, referring to the development, reproduction and transformation of narratives that dramatize world vision and reduce it to a series of metaphors; so drawing on people's relation to the land, the place of gods or remembering decisive events like wars and heroic journeys, these features turn into markers of solidarity [12]. This idea fits Pagan Metal, where the recurring Norse themes of myth, history and nature set an imaginary space beyond mundanity and allows for a social inclusion that goes beyond regional character. Swedish lyrics may appear as an impediment on a larger scale, but national languages are actually one of the markers of the genre and part of its seductive power. In fact it might just well be the definite element of the mentioned subgenre: it's one of the strongest parts of identity; it brings forth a more original and organic feeling [18]. Language enhances the arcane and the same goes for the eerie landscapes which are integrated into this romantic narrative 
of roots at the basis of this leisure life-world. The lyrical samples above are actually some of the few examples of English. This general experience of nostalgia, desire for reenchantment and integration into a mythical collectivity are expressed in a project of shared identity.

The musical style in general due to its sonic, verbal and visual transgressions and stylistic elements of Pagan Metal in particular such as the lyrics massively employing themes of heroic undertakings and recovery of a mythologized heritage comprise both a recreational and a group-binding function. This leisure life-world is straddled between an enchanted past, an inhospitable present and an uncertain future, the former being the place imagined as home [4]; a home constructed by the exploration of the past, in this case of Norse antiquity, and its transformation into a collective memory serving as a cultural resort for anyone wishing for escapism.

Last but not least, in order to gain more insight into the scene and its view of theatrical histories we will take into account some interviews in fanzines offered by Eric Grawsiö, founding member of band Månegarm. First of all, regarding the label Viking Metal itself, he remarks that whereas the band has been assigned various genres in the course of time, labels are not as relevant as togetherness and entertainment, implying that labeling is rather done from the outside. However, neither does he deny it, so it's rather a question of negotiation: "Our music has been put in a lot of different genres during the years. Viking metal works fine for us. We let the listeners and the press decide what to call our music" [19]. Commenting on the connection between musical identity and local heritage, he states that the music has had from the beginning a so-called "Nordic touch", not only due to the usage of Viking narratives, but also due to the folk influenced melodies [20]. Interestingly, by occasionally including female vocals and violins, sonic and gender boundaries are breached, pointing out the ambiguity and fluidity characterizing metal. As for the reasons for invoking such images of a long lost past, the countercultural connotation of Pagan revivalism can be noticed in statements such as: "I think many people are "spiritually lost" in today's modern western world. You choose your own ways in life of course but if you don't feel any connection at all to your own culture and heritage there's a chance of feeling empty and lonely and that can be very destructive for some people and can make people search their happiness in shallow and destructive things. I'm not a religious person at all but I have a respect, interest and fascination for my culture and roots" [21]. Thomas from Thyrfing expresses something of the sort, claiming a deep appreciation of both antiquity and nature, furthermore pointing out the lack of any political purpose in their music [22]. In other words, cultural memory provides a framework for this musical collectivity that constructs meaning through pre-Christian sensibilities and an imaginary identification with distant ancestors now reenacted by musicians themselves. This Norse locality however becomes part of the global culture of metal due to the specific coding encompassing a mixture of themes from the area of fantasy, history, war and so on. As for modernity, that is negotiated too given the use of tech equipment and acceptance of the culture industry. These tensions can also be noticed in the alternate use of Swedish and English, where the latter expresses a desire to appeal to a broad public not only by means of sound.

\section{Conclusions}

The emergence of a Nordic singularity is accomplished through the artistic construction of heritage, that is of a historicized self-presentation [23] providing an imaginative and more than often sublimed antiquity. Popular entertainment actually stages authenticity by combining and arranging symbols in the way that they narrate old stories and their accurate relationship to the present. One might add that mythology and history become interchangeable concepts and they both morph into a larger myth constitutive of a modern social group, in the case at hand the community of symbolic warriors synonymous with the Viking metal scene. Mythological scores and characters are in fact signifiers for the present in need of forms of structuring and historical continuity. There occurs a simulation of a ancestry in a spectacle context which comprises musical, lyrical and visual constituents that create a specific ambiance. Not only old gods and barbarians are important in the story, but other signifiers as well, such as the wilderness of the nature which stands in stark contrast to a modernity already negated by outweighing it with glorious Pagan values. These signifiers contribute to the establishment of a playful leisure life-world where one can experiment reenchantment and empowerment as an escape from mundanity. We can understand this Nordic self-fashioning as some theatrical pose but one that points out the identity struggles in a fragmented postmodernity that gives birth to all kinds of past revivalisms as building blocks for shaping togetherness.

\section{REFERENCES}

[1] K. Kahn-Harris. Extreme Metal: Music and Culture on the Edge, Bloomsbury Academic, Oxford, 2007.

[2] M. Moynihan, D. Søderlind. Lords of Chaos: The Bloody Rise of the Satanic Metal Underground, Feral House, Los Angeles, 2003.

[3] S. Hall. Cultural Identity and Diaspora, Identity, Community, Culture, London, 1990, pp. 222-37.

[4] T. Blackshaw. Myth, Masculinity and Modernity, Routledge, London and New York, 2003.

[5] C. Weedon. Identity and Culture: Narratives of Difference and Belonging, Open University Press, New York, 2004.

[6] E. Hobsbawn, T. Ranger. The Invention of Tradition, Cambridge University Press, Cambridge, 1992. 
[7] Z. Bauman. Intimations of Postmodernity, Routledge, London, 1992.

[8] Erik Grawsiö. Månegarm, Online interview spirit-of-metal.com, May 2007.

[9] V. Vestel. Breakdance, Red Eyed Penguins, Vikings, Grunge and Straight Rock ' $n$ ' Roll: The Construction of Place in Musical Discourse in Rudenga, East Side Oslo, Young Nordic Journal of Youth Research, 7(2), pp. 4-24.

[10] B. Olsson, I. Algulin. Litteraturens historia i Sverige, Studentlitteratur AB, Lund, 1998.

[11] T. Väänänen. Thyrfing, Online interview, available from voicesfromthedarkside.de.

[12] C. Rojek. Leisure Theory. Principles and Practice, Palgrave, London, 2005.

[13] S. Dunn. Lands of Fire and Ice. An Exploration of Death Metal Scenes, Public 29, 2004, pp. 107-125.

[14] T. Hjelm, K. Kahn-Harris, M. Levine. Heavy Metal as Controversy and Counterculture, Popular Music History, No. 6.1./6.2., pp. 5-18.
[15] D. MacCannell. The Tourist. A New Theory of Leisure Class, Berkeley, 1999.

[16] G. Lynch. The Role of Popular Music in the Construction of Alternative Spiritual Identities and Ideologies, Journal for the Scientific Study of Religion, Vol. 45, No. 4, 2006, pp. 481-88.

[17] K. Kahn-Harris. Roots? The Relationship Between the Global and the Local Within the Global Extreme Metal Scene, The Popular Music Studies Reader, London, 2005, pp. 128-136.

[18] P. Lindgren. Thyrfing, Online interview metalbite.com, February 2003.

[19] E. Grawsiö. Månegarm, Online Interview available from valkyrianmusic.com, July 2013.

[20] E. Grawsiö. Månegarm, Online Interview available from destructive-music.com, November 2012.

[21] E. Grawsiö. Månegarm, Online Interview available from metal-temple.com, February 2010.

[22] T. Väänänen. Thyrfing, Online Interview vampster.com, January 2000.

[23] D. Brett. The Construction of Heritage, Cork University Press, Cork, 1996. 